Published in final edited form as:

J Socio Econ. 2013 December ; 47: . doi:10.1016/j.socec.2013.08.007.

\title{
Do Market Incentives Crowd Out Charitable Giving?
}

\author{
Cary Deck ${ }^{\star}$ and Erik O. Kimbrough ${ }^{* *}$ \\ Erik O. Kimbrough: ekimbrough@gmail.com \\ ${ }^{* *}$ Department of Economics, Simon Fraser University, 8888 University Drive, Burnaby, BC \\ V5A1S6, Canada. Phone: 604-374-284
}

\begin{abstract}
Donations and volunteerism can be conceived as market transactions with a zero explicit price. However, evidence suggests people may not view zero as just another price when it comes to prosocial behavior. Thus, while markets might be expected to increase the supply of assets available to those in need, some worry such financial incentives will crowd out altruistic giving. This paper reports laboratory experiments directly investigating the degree to which market incentives crowd out large, discrete charitable donations in a setting related to deceased organ donation. The results suggest markets increase the supply of assets available to those in need. However, as some critics fear, market incentives disproportionately influence the relatively poor.
\end{abstract}

\section{Keywords}

Pro-Social Behavior; Market Incentives; Crowding Out; Organ Donation

\section{Introduction}

Demand for organs has outpaced donor supply to the point that more than 100,000 people in the United States in need of an organ transplant are currently on a waiting list. ${ }^{1}$ In fact, over 6000 Americans die each year while on the waiting list for organ transplants. ${ }^{2}$ Around the world, societies are grappling with ways to reduce the shortage of transplantable organs. Some countries have introduced "presumed consent" or opt-out policies for cadaveric organ donation (see Abadie and Gay, 2006 and Mossialos et al, 2008), and others have begun offering waiting list priority to registered donors (see Kessler and Roth 2012). Another possible approach to solving the organ shortage is the creation of a market for body parts. Since a donation can be viewed as a market transaction with a price of zero, proponents have argued that providing monetary incentives to increase the supply of transplant organs would alleviate shortages and supplement supply provided by altruistic donors (Arrow 1972, Perry 1980, S.H.D. 1985, Mahoney 2000, Becker and Elias 2007). In a recent field experiment, Lacetera, et al. (2012) found that offering economic incentives increased blood donations. However, opponents of a market solution have argued that the commoditization of organs may actually crowd out altruistic motivations and thereby decrease the total quantity

\footnotetext{
(c) 2013 Elsevier Inc. All rights reserved.

*Corresponding Author: 425 WCOB, University of Arkansas, Fayetteville, AR 72701, USA. \& Economic Science Institute, Chapman University.cdeck@walton.uark.edu, Phone: 479-575-6226. Fax: 479-575-3241.

Publisher's Disclaimer: This is a PDF file of an unedited manuscript that has been accepted for publication. As a service to our customers we are providing this early version of the manuscript. The manuscript will undergo copyediting, typesetting, and review of the resulting proof before it is published in its final citable form. Please note that during the production process errors may be discovered which could affect the content, and all legal disclaimers that apply to the journal pertain.

${ }_{1}^{1}$ Statistic from US Dept. of Health and Human Services (http://optn.transplant.hrsa.gov/latestData/rptData.asp)

$2 \mathrm{http} / / /$ organdonor.gov/about/data.html
} 
supplied (Titmuss 1970, Singer 1973, DeJong et al 1995, Byrne and Thompson 2001). Others have highlighted the potential negative distributional consequences of organ markets by pointing to the injustice of a system in which sales are undertaken primarily by the poor and desperate (Borna 1987, Archard 2002, Satz 2008).

Jasper et al (2004) correctly point out that "nothing short of a market test can demonstrate conclusively the impact that incentives would have on the supply of donated organs."(p. 384), but for obvious reasons, policy makers are reluctant to implement such field experiments. However, the issue of whether or not markets crowd out pro-social behavior is much broader than the specific application of transplantable organs. In other settings there is evidence that market incentives crowd out donations and prosocial behavior. In a wellknown study by Gneezy and Rustichini (2000), when a day care introduced small fines for parents who were late picking up their children, the number of children remaining late increased. This is despite the fact that the price for being late increased. Recent research by Falk and Szech (2013) also suggests that introducing market incentives reduces the price at which individuals are willing to allow laboratory mice to be killed. Similarly, Frey and Oberholzer-Gee (1997) report that survey respondents were less willing to tolerate hazardous waste in their community if the residents were to be compensated for its presence than if they were not. Frey (1997) argues that such behavior is being driven by both explicit market incentives and internal intrinsic motivations. Brekke, et al. (2003) develop a model in which agents value their social responsibility, but this perceived responsibility varies with public policy decisions. Their model "implies that economic incentives for voluntary contributions may have adverse effects on contributions. Public policy affects behavior not only through its effect on relative prices and budget and/or time constraints, but also through the policy's effects on individuals' perception of the morally ideal action.” (p. 1969).

Bénabou and Tirole (2006) develop an alternative model where the motivation to charity is based upon how others view the decision maker. They argue that the introduction of explicit rewards for pro-social behavior could discourage the behavior if others are likely to perceive that the person is engaging in the ostensibly pro-social act in order to take advantage of the explicit rewards. Ariely, et al. (2009) find support for this type of motivation in a lab experiment varying the observability of gifts to charities. Similarly, several other studies have found that people behave in a more pro-social manner when their actions can be observed, which provides additional evidence that they are concerned with how others perceive them (see Andreoni and Petrie 2004 and Soetevent 2005 for lab and field evidence, respectively).

This paper adds to the literature exploring the degree to which market incentives crowd out one kind of pro-social behavior in a context where the extrinsic motives are endogenously determined by a market, and agents have complete information about the benefits of their pro-social behavior. In particular, our experiment provides a direct test of the hypothesis that markets crowd out charitable giving in a setting that captures some of the important aspects of deceased organ donation. Subjects choose whether to donate (or sell) a high-value, discrete asset upon their "death". As such, we abstract away from the costs and risks associated with live donations. However, to keep our design simple, we also abstract away from issues of compatibility, quality, and priority which are important concerns in cadaveric organ donation. One important issue that we address directly is the concern expressed by many opponents of organ donation that market incentives may disproportionately impact the relatively poor. Our design allows us to evaluate whether market incentives have differential effects across (experimentally induced) relative wealth levels. Given the level of abstraction and the relatively small stakes of the laboratory, we realize that some readers may not agree with our preferred interpretation that our setting reasonably approximates cadaveric organ transplant. Of course, any laboratory experiment or theoretical model must make 
abstractions, and we believe that our setting captures the general properties of large, discrete donation decisions for assets that outlive their usefulness to their current owners, of which organ transplants from the deceased are but one example.

The next section describes the experimental design used to address these issues. A separate section discusses the behavioral findings that markets need not crowd out donations, but do disproportionately induce the poor to participate. A final section concludes.

\section{Experimental Design}

To explore the impact of market incentives on pro-social behavior, we employ a $3 \times 1$ between subjects experimental design where we vary the economic incentives of engaging in pro-social behavior using an overlapping generations framework. In this setting, each person is endowed with an asset that will generate a payment for either one or three periods, but each person is only able to claim payoffs for up to two periods. After receiving two payments, those with an asset that lasts for three periods can transfer it to someone whose asset only lasts one period and thus could claim an additional payoff. The asset can be thought of as any large, discrete item that has value to someone else beyond the point that it holds value to the original owner, such as an organ. The cost of donation borne by the original owner is sufficiently low so that there is a clear increase in social welfare from doing so. This cost can be thought of as the hassle of registering as a donor or as disgust at the thought of having one's organ harvested. ${ }^{3}$

In each laboratory session there are ten subjects who take turns being active for two periods. This framework allows us to collect multiple observations from each individual and provides an intuitive means for subject to understand the structure of decision problem. In the first period of a session there are three "Young" people and three "Old" people. The other four people are inactive. ${ }^{4}$ In the second period, three of the people who were inactive in the first period become "Young," the three people who were Young in the first period become Old, and the three people who were Old in the first period become inactive. This process repeats after each period and is summarized in Figure 1 from the perspective of a single subject. To avoid issues associated with repeated play games, each Old person must be inactive for one period before becoming active again, the number of inactive people is larger than the next generation, and there is no way to identify other people across lives. ${ }^{5}$ Furthermore, subjects are paid based upon one randomly chosen life.

Each period that an active subject holds a useable asset they receive a specified payment, but the payment depends on the subject's type. Half of the subjects in the session are "Wealthy" and half are "Poor." Wealthy people receive a payment of $\$ 8$ for holding a useable asset when they are Young and $\$ 5$ for holding a useable asset when they are Old. Poor people receive a payment of $\$ 2$ for holding a useable asset when they are Young and $\$ 5$ for holding a useable asset when they are Old. Thus, both Wealthy and Poor people have the same value for a useable asset when they are Old. This is a critical feature of the design so that income levels do not affect the social gains that occur from the transfer of an asset while still

\footnotetext{
${ }^{3}$ Even for live donations such as kidneys where the nominal cost may be quite high, in relative terms these costs are small compared to the value created for the recipient. Given the types of costs that are being modeled, the donor bears the cost whether or not anyone actually uses the asset. The hassle of giving furniture to a charity does not depend on whether or not the furniture is used in the future, and any psychological cost incurred while alive associated with agreeing to be an organ donor at death is not refunded if one's organs are not harvested. For simplicity, recipients bore the same cost from being willing to receive an asset. This cost can be thought of as a loss of pride in having to get help or psychological disgust in the case of taking steps to receive someone else's organ.

"While the experiment was conducted in a neutral frame, terms such as "Young" and "Old" were used to facilitate subject understanding of the decision problem.

5 This approach is commonly used in macroeconomics experiments where the economy outlives individual agents. See e.g. Lim et al. (1994), Marimon and Sunder (1994), and Marimon et al. (1993).
} 
allowing for endogenous wealth differences. Inactive people cannot hold any assets. Each subject remains Poor or Wealthy throughout the entire experimental session; thus generations may differ in the number of Wealthy and Poor people.

The two types of assets were denoted as yellow and green. Yellow assets last for one period. Green assets last for two periods before turning yellow and lasting one additional period. After one period yellow assets become red assets, which have a value of $\$ 0$ to both agent types. In each new generation, two of the four inactive people are endowed with new green assets and one person is endowed with a yellow asset; hence the 50\% and $25 \%$ chance of receiving a green or yellow asset respectively in Figure 1. In this way there are always two people who could transfer an asset to someone to someone in need of one.

Each group of subjects first participates in 20 periods where potential donors and recipients face an opportunity cost of engaging in the donation process. This cost is implemented as forgoing a lottery with a one in one thousand chance of receiving $\$ 100 .^{6}$ In Figure 1, dotted arrows denote paths along which the cost is incurred. While the potential prize is relatively large, a moment's reflection yields that the expected value of the lottery is just ten cents, far less than the $\$ 5$ the asset is worth to someone else. ${ }^{7}$ For potential donors, the lottery cost structure is meant to induce a difficult to justify, knee-jerk reaction against giving up one's asset. After all, market incentives need not be considered if charitable efforts are sufficient to meet needs; nor would donations be desirable if charitable efforts generate net social losses. The expected exchange rate of 1 to 50 from one's own payoff to someone else's is well beyond the level that Andreoni and Miller (2002) found led to considerable altruistic giving. This feature is important because some baseline level of charity is needed in order to be potentially crowded out by the market. We include the opportunity cost for potential recipients for symmetry, though this can be thought of as a cost of seeking out charity, or as a model of psychic costs of being willing to accept charity, or even disgust at having someone else's organ in your body.

After the first 20 periods, groups of subjects either continue in this Baseline environment for another 20 periods or participate in one of the two other treatments. In the Market treatment, a market is introduced that allows people to offer to sell their assets. Donations are still possible in this treatment as one could offer to sell an asset at a price of zero. The NoCost treatment eliminates the opportunity cost of donating an asset. While Market is the primary treatment of interest in determining if introducing market incentives crowd out or supplement charitable giving, the NoCost treatment provides a measure of the degree to which subjects are pro-social and the lottery cost is successful at discouraging charitable giving.

In periods in which there was no market, Old people who owned a green asset (i.e. an asset that was turning yellow and would last one more period) could choose to either "Donate My Asset" or "Keep my Asset" with the default choice being to donate the asset. ${ }^{8}$ Young people with yellow assets chose between "Accept an Asset" and "Keep my Asset." When there was an active market for assets, Old people with green assets chose between "Sell my Asset" and

\footnotetext{
${ }_{7}^{6}$ Subjects playing the lottery tried to guess which integer from 0 to 999 would be randomly selected by the computer.

${ }^{7}$ Risk-averse individuals will value the lottery at less than a dime, and previous experimental work has routinely found that people behave as if they are risk averse (see e.g. Holt and Laury 2002). There is some evidence that people tend to overweight low probability events, but even treating the lottery as a 1 in 100 chance of earning $\$ 100$ yields a value of $\$ 1$ to the owner, still one fifth of the value to the recipient.

${ }^{8}$ Previous work by Samuelson and Zeckhauser (1988) has indentified a "status quo bias" in which people are likely to maintain the default choice. This has been the impetus for organ donation policies in Europe where a person is by default an organ donor unless they take active steps to not be an organ donor. As mentioned above, Abadie and Gay (2006) provide evidence that this policy increases the supply of transplantable organs. As an experimental design choice, this should strengthen any claim that the market "works" since it is competing against the best "real-world" alternative policy.
} 
"Keep my Asset." If the subject selected "Sell my Asset" they also had to enter an asking price between $\$ 0$ and $\$ 5$ in cents. Similarly, Young people with yellow assets chose between "Buy an Asset" and "Keep my Asset" and those who opted to buy an asset had to enter a bid, also between $\$ 0$ and $\$ 5$ in cents. 9

After completing the directions, subjects answered a series of comprehension questions, and an experimenter went over the answers and privately corrected any mistakes. Once all of the subjects had answered the questions correctly, the experiment began. After 20 periods (19 complete generations) of the baseline condition had been completed, subjects in the Market and NoCost treatment were given additional instructions for the last 20 periods of the experiment starting when the $20^{\text {th }}$ generation became Old. For consistency across treatments, subjects in the Baseline condition were also paused and restarted at the half way point. In order to limit the potential influence of forward-looking strategic considerations, subjects were not informed of the number of periods in the instructions; nor were subjects in the Market and NoCost treatments initially informed that the experiment would have two parts. Copies of all directions and the comprehension questions are available in the appendix.

The average salient payment was approximately $\$ 9.25$ and the experiment lasted approximately 45 minutes. Each subject also received a $\$ 7$ participation payment. ${ }^{10}$ Four replications of each of the three treatments were conducted with a total of 120 undergraduate students from Chapman University, a small private school in southern California (53\% male). Some subjects had previously participated in other economics experiments, but none had participated in any related studies.

\section{Behavioral Results}

Our data consist of 480 periods and 960 donation decisions from 12 independent sessions. ${ }^{11}$ Figure 2 displays smoothed time series of average probabilities that at least one asset was donated by treatment. Panel (a) pools the data for the pre-treatment phase when all sessions were in the Baseline treatment (periods 1-20), and panel (b) displays the data for the posttreatment phase for all three treatments separately (periods 21-40). From the figure, we can see a pattern of cooperative decay in the Baseline treatment prior to the introduction of the Market or the No Cost manipulations (see panel a). Similar to standard public goods games which also deal with the tradeoff between own and others' payoffs, we observe a "restart effect" in the Baseline treatment, but the data are quite similar in periods 1-20 and 21-40. More importantly, there is a notable increase in donation rates with the introduction of the treatments (see panel b).

The primary focus of the paper is the degree to which market incentives crowd out private incentives. To address this we estimate the linear probability model using OLS in equation (1) where Supply $_{i t}$ takes a value of 1 if at least one asset is supplied in session $i$ during period $t$ and 0 otherwise. ${ }^{12}$ Since there is a maximum of one unit of demand in any period, this dummy variable indicates whether sufficient supply is available to satisfy any demand.

\footnotetext{
${ }^{9}$ It is possible that the specific market institution employed may impact the degree to which the market encourages or crowds out prosocial behavior, so we chose an institution that tends to generate a relatively low volume of trade. This is likely to induce relatively less incentive to donate; thus, our design may provide a lower bound for the effects of market incentives on pro-social behavior in this setting. Here, market prices were determined as follows. If there was no bid or no ask or the lowest ask was above the bid, then there was no trade. Otherwise the price was the average of the lowest ask and either the bid if there was a single ask or the minimum of the bid and highest ask if there were two asks. In each period with a market, all of the subjects in the session observed a summary report of any bids, asks, or prices.

${ }^{10}$ Subjects also received $\$ 5$ for completing a survey after the experiment. The survey focused on attitudes towards markets for organs 11 All statistics and graphics created using R: A Language and Environment for Statistical Computing (2009). Regressions computed using Harrell (2009) and Warnes (2009).
} 
While we could examine individual donation rates here, from the point of view of welfare, it is less important whether each individual donates than whether there is sufficient supply available to those who are in need. ${ }^{13}$ The independent variables include dummies for the Market and NoCost treatments, the period, and a dummy variable called SecondHalf that takes a value of 1 if the observation was from period $t>20$, and we cluster standard errors at the session level to control for repeated measures. Therefore, the constant term captures giving during the first half of the experiment when everyone experienced the baseline and the SecondHalf variable captures any change in behavior between the first and second half of the experiment that is common to all three treatments. The treatment specific dummies capture deviations of behavior from the second half of the baseline.

$$
\text { Supply }_{i t}=\gamma_{0}+\gamma_{1} \text { Market }_{i t}+\gamma_{2} \text { NoCost }_{i t}+\gamma_{3} \text { Period }_{t}+\gamma_{4} \text { SecondHalf }_{t}+\varepsilon_{i t}
$$

The results of this estimation with standard errors clustered at the session level are shown in Table 1. The main finding is that the Market treatment leads to an increase in supply as captured by the positive and significant coefficient on Market $\left(\gamma_{1}\right)$ in Table 1. This is the basis for finding 1 .

Main Finding 1: Introducing a market does not crowd out charitable giving. Instead, introducing a market leads to an increase in the supply of available assets for transfer.

Several additional aspects of Table 1 are worth noting as well. First, the constant term, $\gamma_{0}$, is positive and significant which indicates that absent the market incentives, people are making donations. However, $\gamma_{0}$ is also significantly less than 1 (p-value $<0.01$ ). This is important because it indicates the experiment was successful in creating an environment where donations covered some but not all of the need. That is, the experiment successfully created a situation where a market could either crowd out charitable giving or supplement it. Similarly, the positive and significant coefficient for the No Cost treatment $\left(\gamma_{2}\right)$ indicates that potential suppliers in the Baseline and Market treatments were not withholding units because of spiteful or competitive preferences but rather because of the cost, despite the 50 to 1 increase in expected value from transferring the asset. The lack of significance for Period $\left(\gamma_{3}\right)$ or SecondHalf $\left(\gamma_{4}\right)$ suggests that the treatment effects are not due to learning or other changes in behavior over the course of the experiment.

Table 1 also reports the results of estimating equation (2), a similar regression to that reported for Supply but where the dependent variable is the period Demand.

$$
\text { Demand }_{i t}=\phi_{0}+\phi_{1} \text { Market }_{i t}+\phi_{2} \text { NoCost }_{i t}+\phi_{3} \text { Period }_{t}+\phi_{4} \text { SecondHalf }_{t}+\varepsilon_{i t}
$$

The results of this regression indicate that the market does not induce more demand. Recall that those in need of an asset also incur an opportunity cost for trying to acquire one. Unsurprisingly, if the opportunity cost is removed demanders virtually always accept an asset ( $\mathrm{p}$-value $=0.39$, for a Wald test of the hypothesis that $\left(\varphi_{0}+\varphi_{2}+\varphi_{4}=1\right)$. As on the supply side, on the demand side there is no evidence of behavior changing over time (i.e. neither $\varphi_{3}$ nor $\varphi_{4}$ are significantly different from 0 ).

\footnotetext{
${ }^{12}$ We report OLS results to ease interpretation by providing a direct estimate of treatment marginal effects, but estimated treatment effects are similar with logistic regression and probit. We also get similar estimates if we use panel regression with random effects for each session and robust standard errors.

${ }^{13}$ Nevertheless, if we perform the analysis at the individual level the results are substantively unchanged.
} 
We now turn to the distributional effects that markets may have on supply. In particular, we want to know if the observed increase in supply when a market is introduced is disproportionately driven by the relatively poor. Figure 3 displays the mean individual probability of supplying an asset in each half of the experiment, by treatment and wealth level.

The data are pooled for the first half of the experiment since all sessions had identical procedures. Clearly, poor subjects exhibit a larger increase in supply in the Market treatment than wealthy subjects, while the effects are similar for the NoCost treatment. To provide statistical support we again rely on OLS regression to estimate of equation (3). ${ }^{14}$ Rather than equation (1), which considered supply at the period level, here the dependent variable is an individual's choice, so Supply $y_{\text {jit }}$ equals 1 if individual $j$ in session $i$ during period $t$ opted to supply an asset. Poorj takes a value of 1 if subject $j$ was Poor and takes a value of 0 otherwise. Fixed effects $\left(\sigma_{i}\right)$ are included for each session, and we cluster standard errors at the individual level to control for repeated measures.

$$
\begin{aligned}
& \text { Supply }_{j i t}=\delta_{0}+\delta_{1} \text { Market }_{i t}+\delta_{2} \text { NoCost }_{i t}+\delta_{3} \text { Poor }_{j}+\delta_{4} \text { Market }_{i t} \times \text { Poor }_{j}+\delta_{5} \text { NoCost }_{i t} \times \text { Poor }_{j}+\delta_{6} \text { Period }_{t}+\delta_{7} \text { SecondHalf }_{t} \\
& \quad+\delta_{8} \text { SecondHalf }_{t} \\
& \quad \times \text { Poor }_{j}+\sum \sigma_{i}+\varepsilon_{j i t}
\end{aligned}
$$

The estimation results, shown in Table 2, indicate that relative wealth does not impact the decision to donate in the Baseline treatment or in the No Cost treatment $\left(\delta_{3}\right.$ and $\delta_{5}$ not statistically different from 0 ). However, relative wealth does affect the decision to supply an asset in the Market treatment. The wealthy are no more likely to supply an asset when a market is introduced ( $\delta_{1}$ is not statistically different from 0 ), but the poor are more likely to supply an asset when a market is introduced ( $\delta_{4}$ is positive and significant, $\mathrm{p}$-value $=0.03$, one-sided test ${ }^{15}$ ). This is the support for the second main finding.

Main Finding 2: The introduction of a market encourages the relatively poor to supply assets while the decisions of the relatively wealthy are not affected by the introduction of a market. Thus, the increase in supply observed with the introduction of a market is driven by actions of the relatively poor.

This result is particularly striking given that relative wealth within the experiment is randomly assigned and the stakes involved likely represent only a miniscule percent of subjects' personal wealth. Yet, those in the role of the "poor" behave differently than the "wealthy". 16

Table 2 also reveals that the effect of removing the opportunity cost of supplying an asset does not differentially affect the poor $\left(\delta_{5}\right.$ is not different from 0$)$. The other coefficients in Table 2 are consistent with those found for estimating equation (1).

\section{Conclusions}

We design a laboratory experiment with overlapping generations to study the degree to which market incentives can be expected to crowd out charitable motives versus providing a

\footnotetext{
${ }^{14}$ As before, our main results are essentially the same if we estimate this model with logit or probit. We prefer OLS because it facilitates easy interpretation of the magnitude of treatment effects.

${ }^{15}$ Given the directional nature of the alternative hypothesis that markets induce the poor to give, a one-sided test is appropriate. A two-sided test is marginally significant $(\mathrm{p}=0.06)$ but the magnitude of the effect is large, suggesting that poor subjects increase their probability of donating by $32 \%$ on average.

16 No demographic information regarding subjects' personal wealth was collected.
} 
supplemental incentive to increase the available supply of a needed asset. Importantly our experimental setting is one in which it is socially optimal for assets to be transferred after they have outlived their usefulness to the original owner, but charity alone is only partially able to solve this problem. Our results clearly demonstrate that market incentives need not crowd out pro-social behavior. This result is important because some recent evidence has suggested the opposite effect will result from the introduction of markets. As there are more calls for market solutions, such as in the case of transplantable organs, it is important to understand the dynamics at play before making policy decisions, which in the case of organs can literally be a matter of life and death.

While our laboratory experiments are stylized, we do find that the introduction of market incentives has a differential effect on relatively wealthy and poor participants. Specifically, we find evidence that market incentives induce the relatively poor to donate while not having a significant effect on the choices of wealthy donors. That such a pattern would emerge is a concern that has been voiced in many policy debates - including being offered as an argument against the creation of organ markets out of fear that the poor would be harvested for the rich. While our experimental markets abstract away from moral and ethical concerns that are present in organ markets (and the stakes are much lower), the fact that we observe this distributional effect when wealthy and poor only differ by a few dollars is striking.

We conclude with a note of caution that our results like any study are, to some degree, specific to the experimental context investigated. In general, extrapolating from level effects observed in a stylized laboratory setting is fraught with issues; though, we would argue that extrapolating from the direction of the comparative static effects is more justified. Thus, our research provides evidence that market incentives can encourage charitable giving.

Moreover, the fact that we observe no crowding out in this setting does not imply that such crowding out is impossible in other settings. As we note in the introduction, a number of well-known experiments find evidence that market incentives can sometimes reduce charitable activities. While our finding that introducing incentives encourages donation is consistent with field experimental evidence on blood drives (Lacetera et al 2013) and lab experimental evidence on organ donation (Kessler and Roth 2012), the tradeoffs between different motivations behind giving (e.g. warm glow vs. explicit incentives) may be different in different settings and are certain to vary across individuals. Indeed, in our market sessions, $50 \%$ of subjects increase their donation rate upon the introduction of the market, while $32 \%$ decrease, and $18 \%$ remain constant, suggesting considerable heterogeneity even in this laboratory setting.

\section{Acknowledgments}

Research support from the NIH-National Institute on Aging (R21AG030184) is gratefully acknowledged, as is research support from the Economic Science Institute at Chapman University. Jennifer Cunningham provided invaluable assistance and Bob Slonim, Bort Wilson, Dave Porter, and participants at Association of Private Enterprise Education and the Southern Economic Association annual meetings provided helpful comments. All errors are our own.

\section{Appendix A: Experiment Instructions}

This is an experiment on economic decision-making. You will be paid in cash at the end of the experiment based upon your decisions and the decisions of others, so it is important that you understand the directions completely. All payoffs are in cents, so $100=\$ 1$. If you have a question at any point, please raise your hand and someone will come to you. Otherwise, you should not communicate with anyone else during the experiment. 
This experiment is broken into a series of periods. In any period there are 3 young, 3 old and 4 inactive people. In the next period the young become old, the old become inactive, and 3 of the inactive people become young. Which inactive people become young is randomly determined, but everyone must be inactive for at least one period after being old and before becoming young again. Notice that there are more inactive people than young people so some people will be inactive for multiple periods.

Young and old people earn money by holding assets (shown on the screen as colored balls). There are three kinds of assets. Red assets last for 1 period and are worth 0 to everyone. Yellow Assets last for 1 period before becoming Red assets. Green assets last for 2 periods, before becoming Yellow assets in the $3^{\text {rd }}$ period. Each period, two young people start with a Green asset and 1 young person starts with a Yellow Asset. This is determined randomly. Notice that a Green asset lasts longer than its initial owner can use it because people earn money while they are young or old, but not while they are inactive.

In the experiment there are wealthy and poor people. Your type is determined randomly and it will not change during the entire experiment.

1. Wealthy people earn 800 from holding a Yellow or Green asset while young.

2. Poor people earn 200 from holding a Yellow or Green asset while young.

Green and Yellow assets are always worth 500 to an old person, regardless of whether the person is Wealthy or Poor. Young people never have Red assets and no one can hold more than one asset.
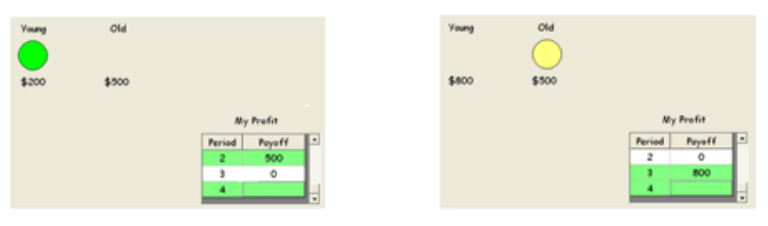

Here are screen images for a Young Poor Person with a Green Asset \& an Old Wealthy Person with a Yellow Asset

Period earnings are shown in the table at the bottom right of the screen (earnings are updated after the period ends). Green rows indicate active periods. Since people cycle through being young, then old, then inactive, active periods come in pairs. After the entire experiment is completed, one pair of active periods will be randomly selected to determine your payoff.

You cannot earn money with an asset when you are inactive; nor can you keep it until you become young again. If you are old and have a Green asset, you can "Keep My Asset" or you can "Donate My Asset." Donating the asset means that a young person with a yellow asset = this period can use your asset next period. Regardless of whether or not an old person donates her asset, she earns 500 in the period in which she was old. The donation occurs in the next period when the old person becomes inactive. The default is to "Donate My Asset." If you want, you can make the donation by pressing "Confirm Choice." If you want to "Keep My Asset" you must first click on this option and then click "Confirm Choice".

If (and only if) an old person chooses "Keep My Asset" she has the opportunity to guess a random number between 0 and 999, inclusive, to earn 10,000 (that is US\$100). You enter a guess by typing it in the box below "Keep My Asset." After each period, everyone in the experiment will be informed of the winning number. 
A young person with a yellow asset has to choose between "Accept New Asset" (the default option) or "Keep My Asset." Accepting an asset means that if an old person donates - an asset then the young person could use it to earn money in the next period after becoming old. A young person who instead opts to "Keep my Asset" will be able to guess a number between 0 and 999, inclusive, to win 10,000. Either choice must be confirmed by pressing the "Confirm Choice" button.

A young person with a green asset will not make a decision (as he automatically keeps his asset), nor will an old person with a yellow or red asset (as this asset has no value in the next period). Inactive people also have no decision to make.

In the following examples (poor) Person A is old in period 6 and (wealthy) Person B is young in period 6 .

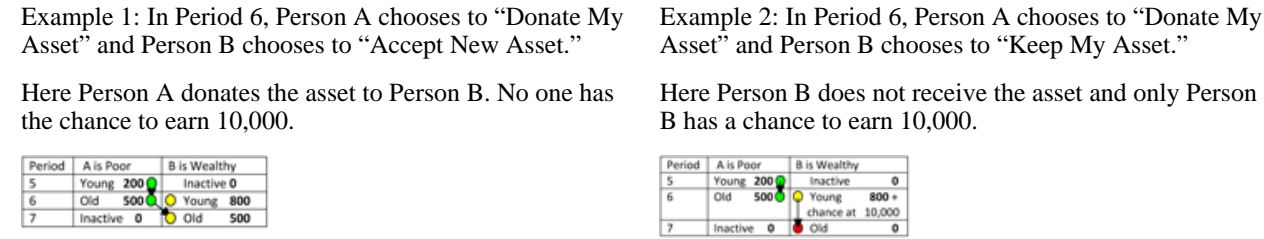

Once you have completed the directions and all of your questions are answered, please press the "Enter ID" button and enter your experiment ID. After you have done this, you will be given a brief quiz, which will not affect your payoff in any way. The quiz is intended to make sure everyone understands how the experiment works and how payoffs are determined. The experiment will begin after everyone has completed the handout and had their responses checked by an experimenter.

\section{NoCost Treatment}

The next set of periods is similar to those you have already completed. The only difference is that there is no longer an opportunity to guess a number and earn 10,000 if you choose to "Keep My Asset."
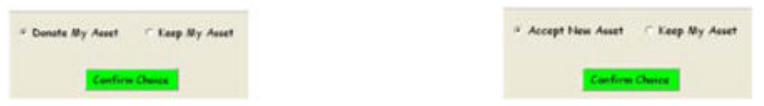

In the following examples (poor) Person A is old in period 6 and (wealthy) Person B is young in period 6 .

Example 1: In Period 6, Person A chooses to "Donate My Asset" and Person B chooses to "Accept New Asset."

Here Person B receives the asset donated by Person A.

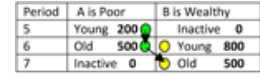

Example 2: In Period 6, Person A chooses to "Donate My Asset" and Person B chooses to "Keep My Asset."

Here Person B does not receive the asset.

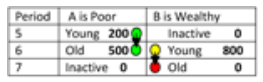

Once you have completed the directions and all of your questions are answered, please wait quietly. The experiment will resume once everyone has completed these directions. Keep in mind that one pair of active periods from the entire experiment will be randomly selected to determine your payoff. 


\section{Market Treatment}

The next set of periods is similar to those you have already completed. The only difference is that instead of assets being donated, you may now buy and sell assets. An old person with a green asset can now choose to "Keep My Asset" or "Sell My Asset." Similarly, a young person with a yellow asset can choose to "Keep My Asset" or "Buy An Asset." Anyone who chooses "Keep My Asset" will still have a chance to earn 10,000 by guessing a number from 0 to 999 , inclusive.
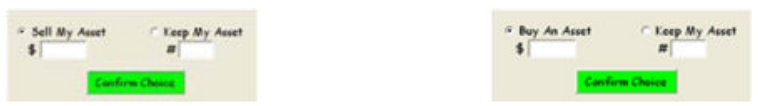

Old people with a green asset can make an offer to sell by typing it into the box below "Sell My Asset." Young people with a yellow asset can make an offer to buy by typing it into the box below "Buy An Asset." Offers to buy and sell must be integer amounts between 0 and 500 (the value to the young person of the asset when he becomes old). You must press "Confirm Choice" after making your decision. One of several things will happen in the market.

1. If no one selects "Sell My Asset" or no one selects "Buy An Asset" then there will be no trade and no price in the market.

2. If the offer to buy is below all offers to sell, then again there will be no trade and no market price.

3. If the offer to buy is greater than only one of the offers to sell then the price is the average of the offer to buy and the lowest offer to sell. The young buyer pays the price to the old person with the lowest offer to sell in exchange for use of the asset in the next period.

4. If the offer to buy is greater than both offers to sell then the price is the average of the two offers to sell. The young buyer pays this price to the old person who made the lowest offer in exchange for use of the asset in the next period.

After each period, everyone in the experiment will be informed of the market price, if it exists, as well as all offers to buy or sell. However, no one will know who made which offer.

The following are three examples of what could occur. In the examples (poor) Person A is old in period 6, (wealthy) Person B is young in period 6, and (wealthy) Person C is old in period 6.

Example 1: In Period 6, Person A chooses to "Sell My Asset" with an offer to sell of 300, Person B chooses to "Buy An Asset" with an offer to buy of 400, and Person C chooses to "Keep My Asset."

Here we have the offer to buy of $400>$ the offer to sell of 300 so the price is 350 (the average of 400 and 300) and Person B buys the asset from Person A. Only Person C has the chance to earn 10,000 since C chose "Keep My Asset."

\begin{tabular}{|c|c|c|c|}
\hline Period & A (Seller) is Poor & B (Buyer) is Wealthy & C is Wealthy \\
\hline 5 & Young 200 & Inactive & Young $800 @$ \\
\hline 6 & $\begin{array}{l}\text { Old }+ \text { Price } \\
500+350=850\end{array}$ & $\begin{array}{l}\text { O Young - Price } \\
800-350=450\end{array}$ & $\begin{array}{l}\text { Old } 5000 \\
+ \text { chance at } 10,000\end{array}$ \\
\hline 7 & Inactive $\mathbf{0}$ & $O$ Old & Inactive $\mathbf{0}$ \\
\hline
\end{tabular}


Example 2: In Period 6, Person A chooses to "Sell My Asset" with an offer to sell of 300, Person B chooses to "Buy An Asset" with an offer to buy of 200, and Person C chooses to "Keep My Asset."

Here we have the offer to buy of $200<$ the offer to sell of 300 so there is no price and Person B does not buy the asset from Person A. Only Person C has the chance to earn 10,000 because C chose "Keep My Asset."

\begin{tabular}{|c|c|c|c|}
\hline Period & A is Poor & $B$ is Wealthy & $\mathrm{C}$ is Wealthy \\
\hline 5 & Young $200 \Omega$ & Inactive & Young $800 \Omega$ \\
\hline 6 & 5000 & $Q$ Young & $\begin{array}{l}\text { Old } 5000 \\
+ \text { chance at } 10,000\end{array}$ \\
\hline 7 & Inactive $\mathbf{0}$ & Old & Inactive $\mathbf{0}$ \\
\hline
\end{tabular}

Example 3: In Period 6, Person A chooses to "Sell My Asset" with an offer to sell of 300, Person B chooses to "Buy An Asset" with an offer to buy of 400, and Person C chooses to "Sell My Asset" with an offer to sell of \$350.

In this case we have the offer to buy of $400>$ both offers to sell of 350 and 300 . The price is 325 (the average of 300 and 350) and Person B buys the asset from Person A. No one has the chance to earn 10,000 because no one chose "Keep My Asset."

\begin{tabular}{|c|c|c|c|}
\hline Period & A (seller) is Poor & B (buyer) is Wealthy & $\mathrm{C}$ is Wealthy \\
\hline 5 & Young $\quad 200$ & Inactive $\mathbf{0}$ & Young $800 \Omega$ \\
\hline 6 & $\begin{array}{l}\text { Old }+ \text { Price } \\
500+325=825\end{array}$ & $\begin{array}{l}\text { Young - Price } \\
800-325=475\end{array}$ & 5000 \\
\hline 7 & Inactive & Old & Inactive $\mathbf{0}$ \\
\hline
\end{tabular}

Once you have completed the directions and all of your questions are answered, please wait quietly. The experiment will resume once everyone has completed these directions. Keep in mind that one pair of active periods from the entire experiment will be randomly selected to determine your payoff.

\section{Appendix B: Quiz Questions}

1. A green asset lasts for how many periods?
a. 1 Period
b. 2 Periods, then it becomes a yellow asset for 1 more period
c. 3 Periods

2. How much does an active agent with a red asset earn in a period?
a. 0
b. 200
c. 500

3. How many periods will an agent be inactive after being old?
a. 1
b. 2
c. Unknown, but at least 1

4. Agents may hold more than one asset at a time.

a. True 
b. False

5. Only an old agent with a green asset and a young agent with a yellow asset may choose to "Keep My Asset".

a. True

b. False

6. If an old agent with a green asset chooses to "Donate My Asset", then that agent will be able to guess a number between 0 and 999 in hopes of earning $\$ 100$.
a. True
b. False

7. If a young agent with a yellow asset chooses to "Keep My Asset", that agent will be unable to receive a donated asset.
a. True
b. False

\section{NoCost Alternate Questions}

6. Old agents with yellow assets may choose to "Donate My Asset" to young agents with yellow assets.
a. True
b. False

7. If a young agent with a yellow asset chooses to "Keep My Asset", that agent will be unable to receive a donated asset.
a. True
b. False

\section{Market Alternate Questions}

6. Only an old agent with a green asset may choose to "Sell My Asset".
a. True
b. False

7. If an old agent with a green asset chooses to "Sell My Asset", then that agent will be able to guess a number between 0 and 999 in hopes of earning $\$ 100$.
a. True
b. False

\section{References}

Abadie, Alberto; Gay, Sebastien. The Impact of Presumed Consent Legislation on Cadaveric Organ Donation: A Cross-Country Study. Journal of Health Economics. 2006; 25(4):599-620. [PubMed: 16490267]

Andreoni, James; Miller, John. Giving According to GARP: an Experimental Test of the Consistency of Preferences for Altruism. Econometrica. 2002; 70(2):737-53.

Andreoni, James; Petrie, Regan. Public Goods Experiments without Confidentiality: A Glimpse into Fund-raising. Journal of Public Economics. 2004; 88(7-8):1605-23. 
Archard, David. Selling Yourself: Titmuss's Argument Against a Market in Blood. Journal of Ethics. 2002; 6(1):87-103. [PubMed: 14686328]

Arrow, Kenneth J. Gifts and Exchanges. Philosophy and Public Affairs. 1972; 1(4):343-362.

Borna, Shaheen. Morality and Marketing Human Organs. Journal of Business Ethics. 1987; 6(1):3744. [PubMed: 11658825]

Byrne, Margaret M.; Thompson, Peter. A Positive Analysis of Financial Incentives for Cadaveric Organ Donation. Journal of Health Economics. 2001; 20(1):69-83. [PubMed: 11148872]

D SH. Regulating the Sale of Human Organs. Virginia Law Review. 1985; 71(6):1015-1038. [PubMed: 11649755]

DeJong, William; Drachman, Jessica; Gortmaker, Steven L.; Beasley, Carol; Evanisko, Michael J. Options for Increasing Organ Donation: The Potential Role of Financial Incentives, Standardized Hospital Procedures, and Public Education to Promote Family Dicussion. The Milbank Quarterly. 1995; 73(3):463-479. [PubMed: 7659048]

Dukeminier, Jesse, Jr. Supplying Organs for Transplantation. Michigan Law Review. 1970; 68(5): 811-866.

Falk, Armin; Szech, Nora. Morals and Markets. Science. 2013; 340:707-711. [PubMed: 23661753]

Frey, BS. An Economic Theory of Personal Motivation. Edward Elgar; Cheltenham, UK: 1997. Not Just for the Money.

Frey BS, Oberholzer-Gee F. The cost of price incentives: An empirical analysis of motivation crowding-out. American Economic Review. 1997; 87(4):746-755.

Gneezy U, Rustichini A. A fine is a price. The Journal of Legal Studies. 2000b; 29(31, Part 1):1-17.

Holt, Charles A.; Laury, Susan K. Risk Aversion and Incentive Effects. The American Economic Review. 2002; 92(5):1644-1655.

Jasper JD, Nickerson Carol AE, Ubel Peter A, Asch David A. Altruism, Incentives, and Organ Donation: Attitudes of the Transplant Community. Medical Care. 2004; 42(4):378-386. [PubMed: 15076815]

Kessler, Judd B.; Roth, Alvin E. Organ Allocation Policy and the Decision to Donate. American Economic Review. 2012; 102(5):2018-2047.

Lacetera N, Macis M, Slonim Robert. Will there be blood? Incentives and Displacement Effects in Pro-Social Behavior. American Economic Journal, Economic Policy. 2012; 4(1):186-223.

Lim, Suk S.; Prescott, Edward C.; Sunder, Shyam. Stationary Solution to the Overlapping Generations Model of Fiat Money: Experimental Evidence. Empirical Economics. 1994; 19(2):255-77.

Mahoney, Julia D. The Market for Human Tissue. Virginia Law Review. 2000; 86(2):163-223. [PubMed: 12718304]

Marimon, Ramon; Spear, S.; Sunder, Shyam. Expectationally-driven Market Volatility: An Experimental Study. Journal of Economic Theory. 1993; 61(1):74-103.

Marimon, Ramon; Sunder, Shyam. Expectations and Learning Under Alternative Monetary Regimes: An Experimental Approach. Economic Theory. 1994; 4(1):131-162.

Mossialos, Elias; Costa-Font, Joan; Rudisill, Caroline. Does Organ Donation Legislation Affect Individuals' Willingness to Donate Their Own or Their Relative's Organs? Evidence from European Union Survey Data. BMC Health Services Research. 2008; 8(48):1-10. [PubMed: 18173837]

Perry, Clifton. Human Organs and the Open Market. Ethics. 1980; 91(1):63-71. [PubMed: 11661873]

R Development Core Team. R: A language and environment for statistical computing. R Foundation for Statistical Computing; Vienna, Austria: 2009. ISBN 3-900051-07-0, URL http://www.Rproject.org

Samuelson, William; Zeckhauser, Richard. Status Quo Bias in Decision Making. Journal of Risk and Uncertainty. 1988; 1(1):7-59.

Satz, Debra. The Moral Limits of Markets: The Case of Human Kidneys. The Proceedings of the Aristotelian Society. 2008; 108(3):269-288.

Singer, Peter. Altruism and Commerce: A Defense of Titmuss Against Arrow. Philosophy and Public Affairs. 1973; 2(3):312-320. [PubMed: 11662142] 
Titmuss, Richard. The Gift Relationship: From Human Blood to Social Policy. George, Allen \& Unwin; London: 1970.

Warnes, Gregory R. gtools: Various R programming tools. R package version 2.6.1. 2009. http:// CRAN.R-project.org/package=gtools. Includes R source code and/or documentation contributed by Ben Bolker and Thomas Lumley 


\section{Highlights}

Recent evidence suggests a tension between pro-social behavior and markets.

An experiment examines the degree to which markets crowd-out donations.

Market incentives are found to increase the capacity for assisting those in need.

Introducing market incentives disproportionality affects the relatively poor. 


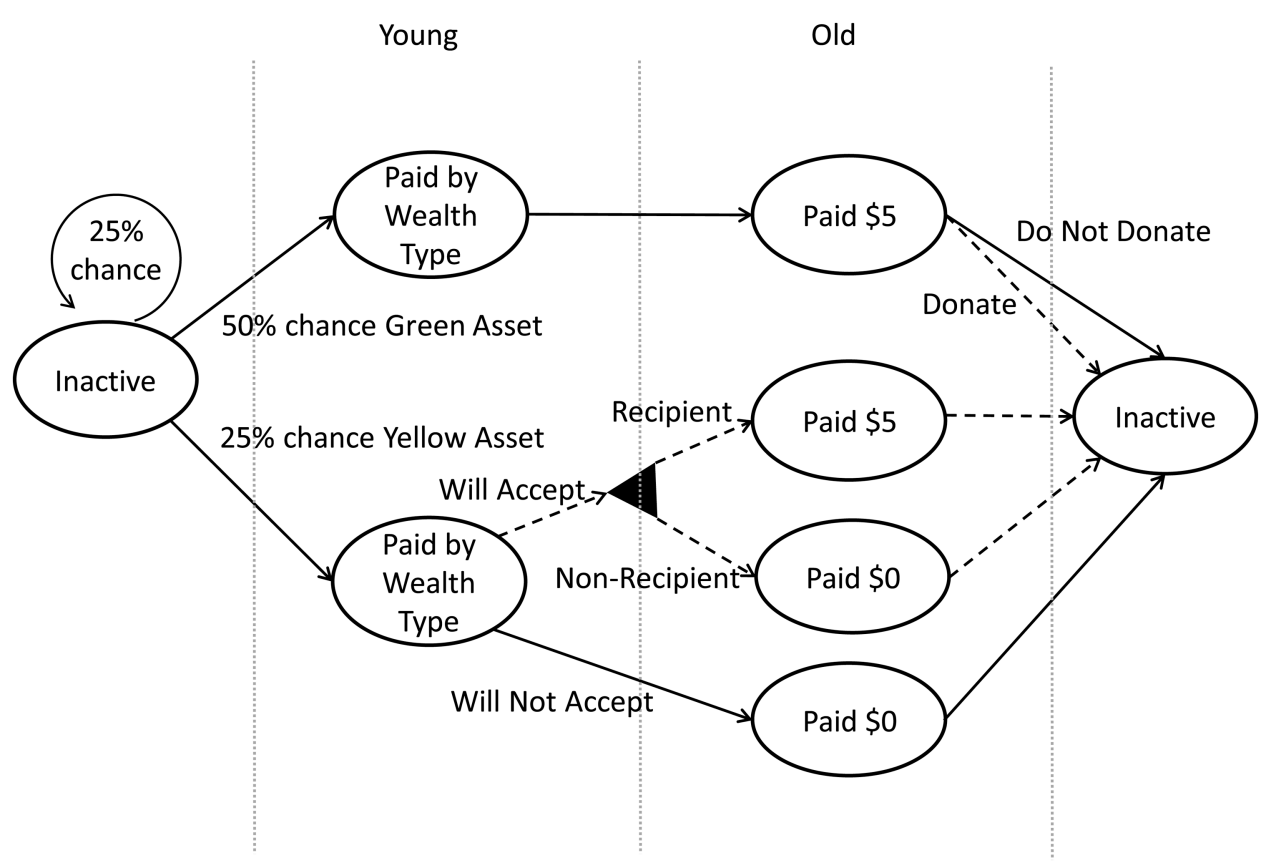

Figure 1.

The Life-Cycle of a Single Agent. 


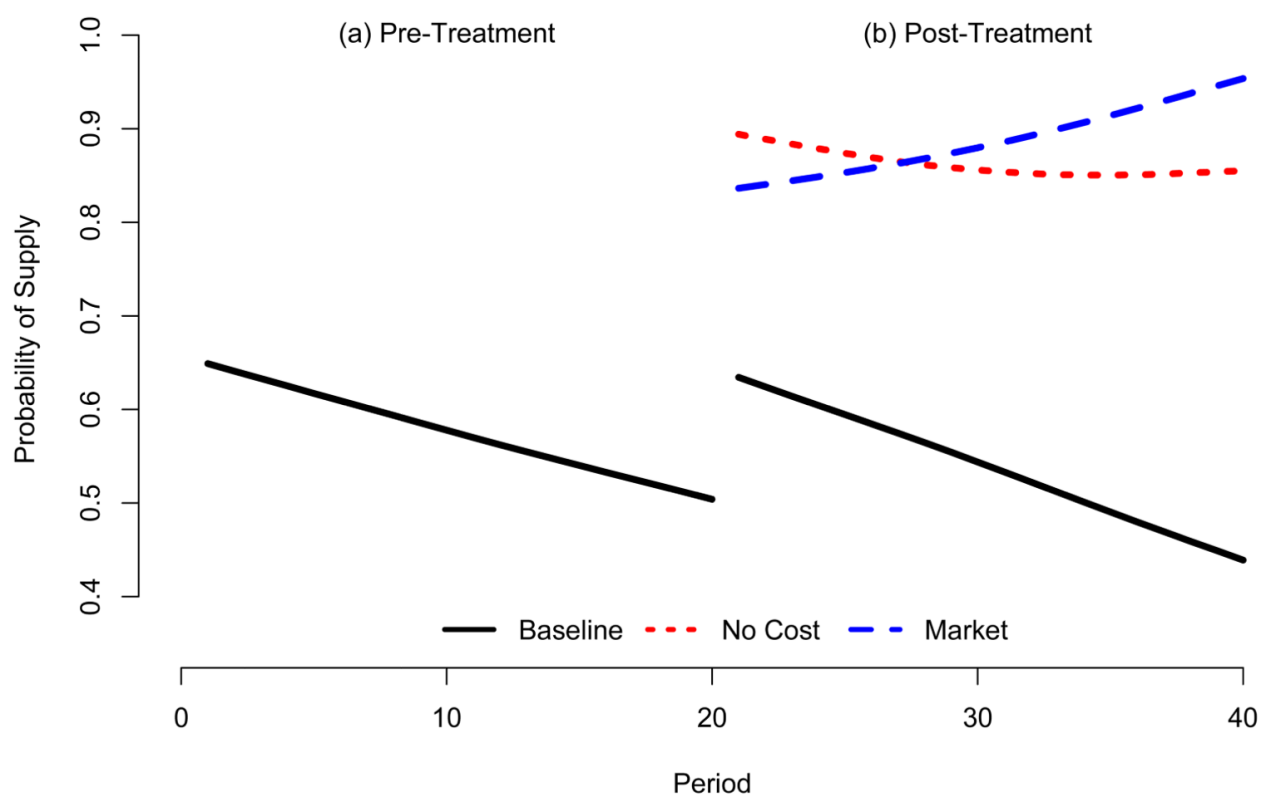

Figure 2.

Time Series of Supply Probability by Treatment, Smoothing Splines. 


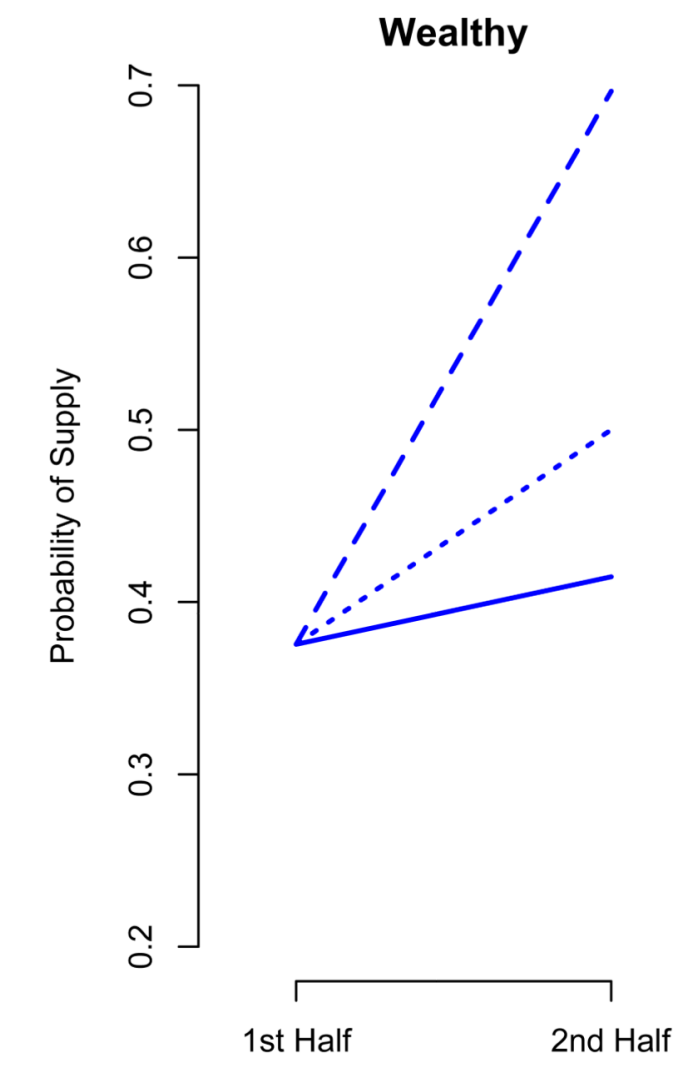

Wealthy
Poor

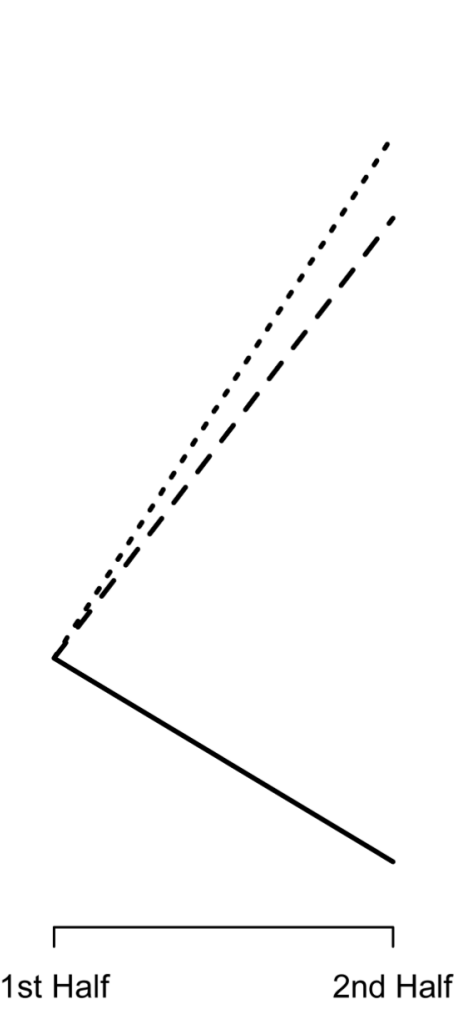

\section{- Baseline - - NoCost ... Market}

Figure 3. Probability of Supply by Treatment and Wealth Level 
Table 1

Treatment Effects on Deaths, Demand and Supply

\begin{tabular}{|c|c|c|}
\hline & \multicolumn{2}{|c|}{ Dependent Variable } \\
\hline & $\begin{array}{l}\text { Supply }_{i t} \\
\text { equation (1) }\end{array}$ & $\begin{array}{l}\text { Demand }_{i t} \\
\text { equation (2) }\end{array}$ \\
\hline \multirow[t]{2}{*}{ Constant } & $0.63^{* * *}$ & $0.72^{* * *}$ \\
\hline & $(0.05)$ & $(0.05)$ \\
\hline \multirow[t]{2}{*}{ Market } & $0.35^{* *}$ & 0.01 \\
\hline & $(0.15)$ & $(0.08)$ \\
\hline \multirow[t]{2}{*}{ No Cost } & $0.33^{*}$ & $0.20^{* *}$ \\
\hline & $(0.15)$ & $(0.07)$ \\
\hline \multirow[t]{2}{*}{ Period } & -0.01 & -0.00 \\
\hline & $(0.00)$ & $(0.00)$ \\
\hline \multirow[t]{2}{*}{$2^{\text {nd }}$ Half } & 0.06 & -0.04 \\
\hline & $(0.11)$ & $(0.12)$ \\
\hline $\mathrm{N}$ & 320 & 320 \\
\hline
\end{tabular}

The dependent variables are binary and indicate at least one asset is supplied or demanded in period t of session i. Standard errors clustered by Session are in parentheses.

*** $\mathrm{p} \leq 0.01$

** $\mathrm{p} \leq 0.05$,

p $\leq 0.1$ for two sided test of null that coefficient $=0$. 
Table 2

The Effects of Poverty on the Choice to Supply

\begin{tabular}{ll}
\hline & $\begin{array}{l}\text { Supply }_{\text {itt }} \\
\text { equation (3) }\end{array}$ \\
\hline Constant & $0.44(0.09)^{* * *}$ \\
Market & $0.003(0.11)$ \\
No Cost & $0.20(0.11)^{*}$ \\
Poor & $-0.06(0.06)$ \\
Period & $-0.003(0.003)$ \\
Market $\times$ Poor & $0.32(0.17)^{*}$ \\
No Cost $\times$ Poor & $0.07(0.15)$ \\
$2^{\text {nd }}$ Half & $0.14(0.09)$ \\
$2^{\text {nd }}$ Half $\times$ Poor & $-0.12(0.10)$ \\
\hline $\mathrm{N}$ & 960 \\
\hline
\end{tabular}

The binary dependent variable is the individual decision of person $\mathrm{j}$ in period $\mathrm{t}$ of session $\mathrm{i}$. OLS regression with session fixed effects. Clustered standard errors in parentheses.

$* * *$

$\mathrm{p} \leq 0.01$

** $\mathrm{p} \leq 0.05$

${ }^{*} \mathrm{p} \leq 0.1$ for a two-sided test of null that coefficient $=0$. 